\title{
DEVELOPMENT OF THE "DISSOLUTION" TEST FOR BISOPROLOL TABLETS
}

\author{
O.O.Vislous, N.Yu.Bevz, V.A.Georgiyants, N.V.Zhivora \\ National University of Pharmacy
}

Key words: bisoprolol; tablets; "Dissolution" test; spectrophotometry; validation

\begin{abstract}
Bisoprolol is a lipophilic cardioselective $\beta$-blocker, which leads to its rapid and almost complete (90\%) absorption out of the gastrointestinal tract and high bioavailability. For determination bioavailability of solid dosage forms for oral administration in the conditions of pharmaceutical companies and laboratories the "dissolution" test is performed; its results allow to judge about the technology of manufacturing the drug and its bioavailability. The test on dissolution of solid dosage forms is an integral part of measures ensuring the quality of medicines. The aim of the analysis is to develop the "dissolution" test for bisoprolol tablets by absorption spectrophotometry in the ultraviolet and visible spectra. As a result of the research, the conditions for conducting the "dissolution" test for bisoprolol fumarate tablets have been grounded: the device with the blade is used, the volume of the medium is $500 \mathrm{ml}$, the temperature of the solvent medium is $37^{\circ} \mathrm{C}$, the solvent is $0.1 \mathrm{M}$ hydrochloric acid, the rotation rate is $75 \mathrm{rpm} / \mathrm{min}$, the dissolution time is $20 \mathrm{~min}$. The spectrophotometric method of determination of bisoprolol fumarate in $0.1 \mathrm{M}$ solution of hydrochloric acid at the wavelength of $272 \mathrm{~nm}$ has been developed. It has been determined that the tablet excipients do not prevent spectrophotometric determination. The results obtained have shown that for 20 minutes of dissolution more than $90 \%$ of the active substance of its label claim turns into the solution. The following validation properties do not exceed the eligibility criteria: robustness (the analytical solution is stable for an hour), linearity $(a=0.97 \% \leq \max a, 1.92 \% ; b=0.9931)$, the correlation coefficient $(0.9999)$, accuracy $(0.52 \% \leq \max \delta$, $0.96 \%)$ and repeatability $(2.24 \% \leq \max \Delta a s, 3.0 \%)$, precision (1.42\% $\leq \max \Delta$ as $3.0 \%)$, which allows us to recommend the procedure for use in pharmaceutical analysis.
\end{abstract}

Since drug treatment of hypertension should be conducted regularly and for a long time, the medicines prescribed for that purpose must be easy in use and welltolerated by patients. Easiness of use in the first place is the ability to take the medication once a day. Bisoprolol, a highly selective $\beta$-blocker (BB) $[6,8]$ belongs to such medicines.

When treating hypertension medicines with the selective action gain the advantage as, on the one hand, they do not yield to non-selective BB by their properties, and, on the other hand, they have undesirable and side effects much more rarely. Bisoprolol does not interact with any of the drugs used to treat cardiovascular disease and rarely shows many side and undesirable effects [6-8].

Dissolution is one of the most important pharmacotechnological characteristics of solid dosage forms, tablets in particular, which allows not only to investigate the technology of producing the dosage form, but also to study its bioavailability $[2,3]$.

In accordance with the requirements of the USP and Japanese Pharmacopoeia dissolution of bisoprolol tablets is carried out in water, the amount of the active substance dissolved is determined by liquid chromatography $[9,10]$.

The aim of our research is to develop the "Dissolution" test for bisoprolol tablets by absorption spectrophotometry in the ultraviolet and visible spectra.

\section{Materials and Methods}

The object of the study was bisoprolol tablets of three domestic manufacturers. One tablet contains $10 \mathrm{mg}$ of bisoprolol fumarate. To prepare the working standard sample the substance of bisoprolol fumarate, batch 130501 (India), excipients and reagents that meet the requirements of the SPhU were used.

Analytical studies were performed using an Evolution 60S spectrophotometer; the Pharma Test - DT 70 device for dissolution determination, “AXIS" ANG 200 analytical balance (Poland). All tests were performed using the measuring glassware of class A.

\section{Results and Discussion}

Determination of the "Dissolution" test was performed in accordance with the requirements of the State Pharmacopoeia of Ukraine $[4,5]$. The generally accepted method for determining dissolution of tablets besides the chromatographic one is the spectrophotometric method. To develop the method for dissolving bisoprolol fumarate tablets we have studied the spectral characteristics of the medicinal substance in the range from $220 \mathrm{~nm}$ to $300 \mathrm{~nm}$ in water and $0.1 \mathrm{M}$ solution of hydrochloric acid (Fig. 1).

The absorption spectrum of an aqueous solution of bisoprolol fumarate (Fig. 1) is characterized by absorption maxima at wavelengths of $229 \mathrm{~nm}, 271 \mathrm{~nm}$ and a shoulder at $276 \mathrm{~nm}$. When changing the solvent to $0.1 \mathrm{M}$ solution of hydrochloric acid the nature of the spectrum 


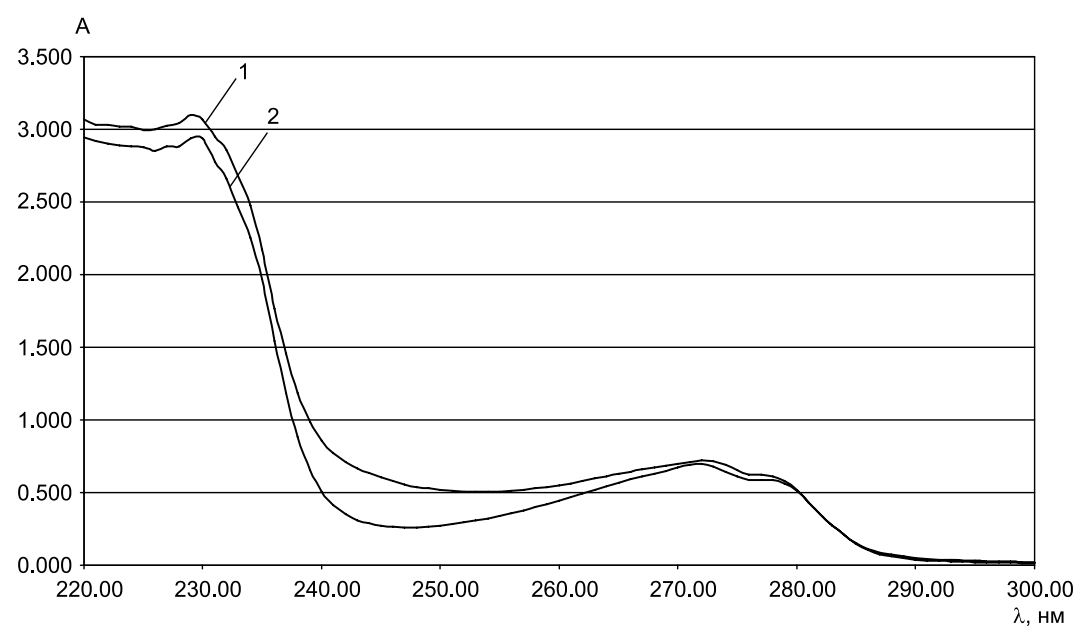

Fig. 1. UV absorption spectra of bisoprolol fumarate in water (1) and $0.1 \mathrm{M}$ solution of hydrochloric acid (2).

Table 1

The study of stability of the analytical solution

\begin{tabular}{|c|c|c|c|c|c|c|}
\hline \multirow{2}{*}{ No. of solution } & \multicolumn{5}{|c|}{ Term stability studies, $\mathrm{t}$, min } & \multirow{2}{*}{ Average } \\
\cline { 2 - 6 } & 0 & 15 & 30 & 45 & 60 & 0.253 \\
\hline $\mathrm{A}_{\mathrm{st}}$ & 0.255 & 0.255 & 0.251 & 0.251 & 0.252 & 0.253 \\
\hline
\end{tabular}

does not change and peaks are observed at wavelengths between $230 \mathrm{~nm}$ and $272 \mathrm{~nm}$.

When studying the obedience of bisoprolol fumarate solutions in various solvents to Bouguer-LambertBeer law it has been found that there is a direct correlation in water and $0.1 \mathrm{M}$ solution of hydrochloric acid in the concentration of the active substance from $4.0 \times 10^{-5}$ to $2.8 \times 10^{-4} \mathrm{~g} / \mathrm{ml}$.

The dissolution medium was chosen taking into consideration the nature of the substance studied and the area of the digestive tract where it should be dissolved. Because of bisoprolol fumarate absorption occurs in the stomach $0.1 \mathrm{M}$ solution of hydrochloric acid was used as a dissolution medium, its $\mathrm{pH}$ is 1.0 corresponding to the $\mathrm{pH}$ of the gastric juice.
The check of solutions' stability was performed for 60 minutes for the standard solution (Table 1). It has been determined that the analytical solution is stable for one hour.

It has been found that bisoprolol fumarate absorption spectra in $0.1 \mathrm{M}$ solution of hydrochloric acid obtained from the tablet mass of different manufacturers fully coincide with the UV absorption spectrum of the standard sample of bisoprolol fumarate (Fig. 2). One can predict that tablet excipients do not affect the nature of the absorption spectrum of the active substance. Therefore, we recommend to conduct the "Dissolution" test at the wavelength of $272 \mathrm{~nm}$.

The time of conducting the "Dissolution" test, the number of tablets and the average volume were determined

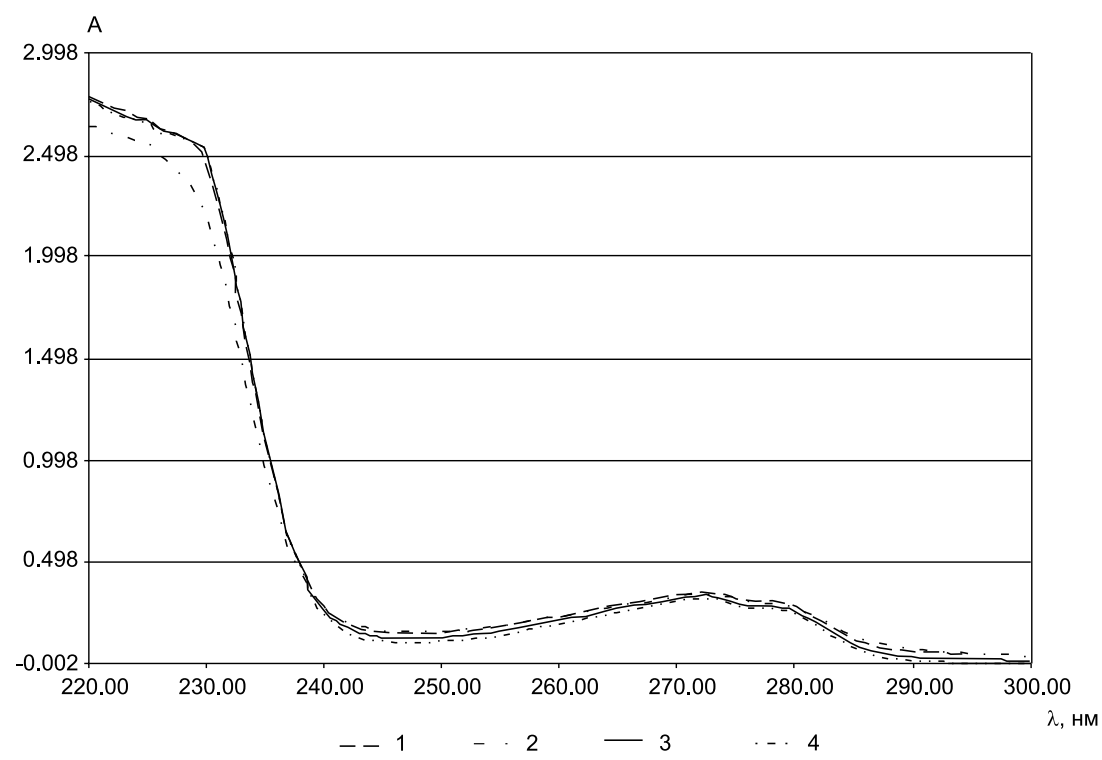

Fig. 2. The absorption spectra of bisoprolol fumarate obtained from the tablet mass of different manufacturers $(1,2,3)$ and the standard solution (4). 


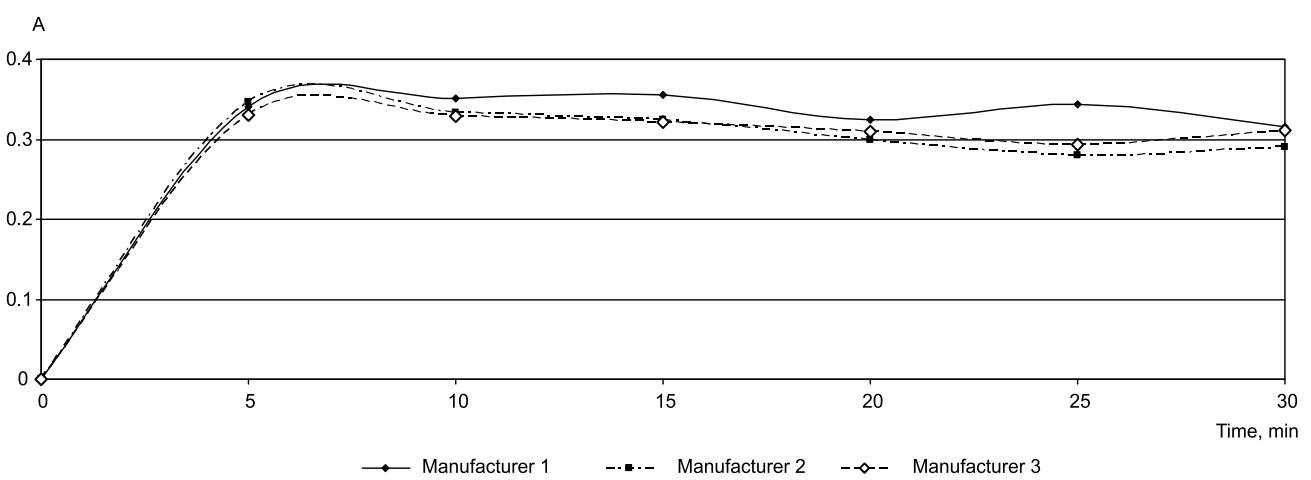

Fig. 3. The bisoprolol fumarate release profile of the medicine under studyof different manufacturers in $0.1 \mathrm{M}$ solution of hydrochloric acid.

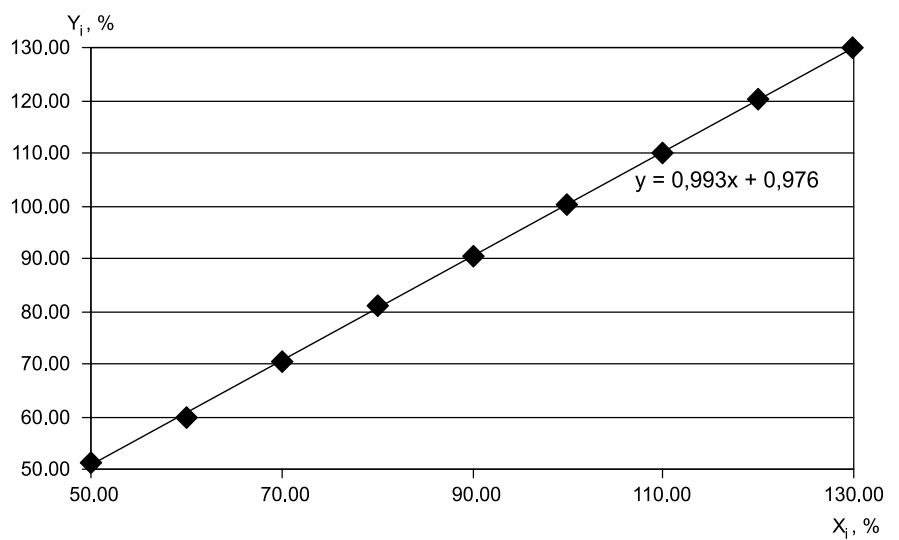

Fig. 4. The linear dependence of the optical density on the concentration of bisoprolol fumarate in the normalized coordinates.

experimentally. To determine the dissolution time the kinetics of bisoprolol release from tablets was studied (Fig. 3).

The experimental data (Fig. 3) testify that solubility of bisoprolol fumarate is relatively high since for the first 5 minutes the release of almost all of the active ingredient occurs. Thus, we consider 20 minutes as the optimal time for dissolving bisoprolol tablets.

The amount of bisoprolol fumarate in tablets is $5 \mathrm{mg}$ or $10 \mathrm{mg}$, so to conduct the "Dissolution" test by spectrophotometry and to obtain more accurate results we recommend to take 5 tablets and the volume of the medium should be $500 \mathrm{ml}$. Determination was performed at $75 \mathrm{rpm} / \mathrm{min}$.

On the basis of these studies the conditions of dissolution determination for bisoprolol tablets have been developed: the number of bisoprolol tablets, $10 \mathrm{mg}$, is 5 ; the solvent is $0.1 \mathrm{M}$ hydrochloric acid, the volume of the dissolution medium is $500 \mathrm{ml}$, the rotation rate is $75 \mathrm{rpm} / \mathrm{min}$, the dissolution time is $20 \mathrm{~min}$. For 20 minutes not less than $90 \%$ of bisoprolol of its label claim must be released.

Linearity of the method was investigated in the concentration range from $50 \%$ to $130 \%$ of the nominal concentration. The ratios of the mean values of optical densities for each of 9 solutions (the measurements was performed three times to confirm authenticity) to the average value of the optical density of the reference solution were calculated, obtaining values $\mathrm{X}_{\mathrm{i}}=\mathrm{C}_{\mathrm{i}} / \mathrm{C}_{\mathrm{st}} \cdot 100 \%$, $Y_{i}=\left(A_{i} / A_{s t}\right) \cdot 100$. Calculations were performed in the normalized coordinates, giving concentration and analytical signal as a percentage of the nominal values. The value of $\mathrm{Z}=100 \bullet\left(\mathrm{Y}_{\mathrm{i}} / \mathrm{X}_{\mathrm{i}}\right)$ being the concentration found as a percentage to the introduced concentration was also determined (Fig. 4) [1, 9].

The results of the statistical calculation of linearity are given in Table 2.

The method is characterized by sufficient convergence and accuracy within the whole range of concentrations of $50-130 \%$ of that observed from the results, which are shown in Table 3.

\section{The method of determination:}

Absorption spectophotometry in the ultraviolet region, the method of standard.

Dissolution medium: $0.1 \mathrm{M}$ hydrochloric acid, $500 \mathrm{ml}$.

Equipment: the rotation rate is $75 \mathrm{rpm} / \mathrm{min}$.

Dosage unit: the required amount of tablets for providing the summary content of bisoprolol fumarate of $50 \mathrm{mg}$ in the vessel for dissolution.

Dissolution time: 20 minutes.

Test solution: A filtrate is used.

Table 2

Results of the linearity study

\begin{tabular}{|c|c|c|}
\hline Constants & Found & $\begin{array}{c}\text { Values for the } \\
\text { SPhU }\end{array}$ \\
\hline $\mathrm{b}$ & 0.9931 & \\
\hline $\mathrm{S}_{\mathrm{b}}$ & 0.01 & \\
\hline $\mathrm{a}$ & 0.97 & $\max , \mathrm{a}=1.92 \%$ \\
\hline $\mathrm{S}_{\mathrm{a}}$ & 0.50 & \\
\hline $\begin{array}{l}\text { The residual standard } \\
\text { deviation } \mathrm{S}_{0}\end{array}$ & 0.42 & $\max , \mathrm{S}_{\mathrm{o}}=1.58 \%$ \\
\hline $\mathrm{r}$ & 0.9999 & $\min , \mathrm{r}=0.9987$ \\
\hline
\end{tabular}


The results of analysis for model mixtures and their statistical processing

\begin{tabular}{|c|c|c|c|c|}
\hline $\begin{array}{l}\text { No. of the } \\
\text { model } \\
\text { solution }\end{array}$ & $\begin{array}{l}\text { Introduced in \% to the } \\
\text { concentration of the } \\
\text { reference solution }\left(\mathrm{X}_{\text {ifact }} \%\right)\end{array}$ & $\begin{array}{l}\text { Optical density } A_{i} \\
\left(A_{s t}=0.317\right)\end{array}$ & $\begin{array}{l}\text { Found in } \% \text { to the } \\
\text { concentration of the } \\
\text { reference solution }\left(\mathrm{Y}_{\mathrm{i}} \%\right)\end{array}$ & $\begin{array}{l}\text { Found in } \% \text { to the } \\
\text { introduced } Z_{i}=100\left(Y_{i} / X_{i}\right)\end{array}$ \\
\hline 1 & 50.00 & 0.162 & 51.10 & 102.21 \\
\hline 2 & 60.00 & 0.190 & 59.94 & 99.89 \\
\hline 3 & 70.00 & 0.223 & 70.35 & 100.50 \\
\hline 4 & 80.00 & 0.257 & 81.07 & 101.34 \\
\hline 5 & 90.00 & 0.286 & 90.22 & 100.25 \\
\hline 6 & 100.00 & 0.317 & 100.00 & 100.00 \\
\hline 7 & 110.00 & 0.349 & 110.09 & 100.09 \\
\hline 8 & 120.00 & 0.381 & 120.19 & 100.16 \\
\hline 9 & 130.00 & 0.413 & 130.28 & 100.22 \\
\hline \multirow{2}{*}{\multicolumn{4}{|c|}{$\begin{array}{r}\text { Mean, Z\% } \\
\text { Relative standard deviation, Sz\% }\end{array}$}} & 100.52 \\
\hline & & & & 0.7641 \\
\hline \multicolumn{4}{|c|}{ Relative confidence interval $\Delta \mathrm{as} \%=\mathrm{t}(95 \%, 8)^{*} \mathrm{Sz}$} & 1.4209 \\
\hline \multicolumn{4}{|c|}{ Critical value for convergence of results $\Delta$ as $\%$} & $3.0 \%$ \\
\hline \multicolumn{4}{|c|}{ Systematic error $\delta$} & 0.52 \\
\hline \multicolumn{4}{|c|}{$\begin{array}{r}\text { Criterion of the systematic error insignificance } 1) \delta \leq \Delta \text { as } /(\mathrm{g})^{\wedge} 0.5=0.72 / \sqrt{ } 9, \\
\text { 2) if not satisfied } 1) \text {, then, } \delta \leq 0.72\end{array}$} & 0.24 \\
\hline \multicolumn{4}{|c|}{ The overall conclusion of the method } & Correct \\
\hline
\end{tabular}

Reference solution: This solution of the standard sample of bisoprolol fumarate is prepared in $0.1 \mathrm{M}$ solution of hydrochloric acid with the concentration of bisoprolol fumarate being similar to the concentration of the test solution.

Compensation solition: $0.1 \mathrm{M}$ solution of hydrochloric acid.

The optical density of the test solution and the reference solution is measured at the wavelength of $272 \mathrm{~nm}$ in relation to the compensation solution.

Limitation: not less than $90 \%$ of the label claim of bisoprolol fumarate.

\section{CONCLUSIONS}

1. The method of the "Dissolution" test of bisoprolol fumarate tablets has been developed, and the optimal conditions for its conducting are the medium and the volume of dissolution, the rotation rate, the time of dissolution. The results obtained have shown that for 20 minutes of dissolution at least $90 \%$ of bisoprolol fumarate of its label claim turns into the solution.

2. As a result of the validation test method performance «Dissolution» of bisoprolol tablets may be recommended for introduction in the book «Bisoprolol fumarate tablets» in the State Pharmacopoeia of Ukraine.

\section{REFERENCES}

1. Багирова В.Л., Гризодуб А.И., Чибиляев Т.Х. и др. Руководство по валидации методик анализа лекарственных средств. - М.: Фарм. пром., 2007. - 58 с.

2. Гризодуб А.И. Стандартизованные проиедуры валидации методик контроля качества лекарственных средств // В кн.: «Аналитическое обеспечение создания, стандартизачии и контроля качества лекарственных средств». - Х.: «НТМТ», 2011. - T. 1. - С. 934-1063.

3. Гризодуб А.И., Леонтьев Д.А., Дмитриева М.В. // Фармаком. - 2006. - №4. - С. 39-50.

4. Державна фармакопея Украӥни / Державне підприємство «Науково-експертний фармакопейний центр». 1-е вид. - Доп. 1. - Х.: Державне підприємство «Науково-експертний фармакопейний иентр», 2004. $520 \mathrm{c}$

5. Державна фармакопея України / Державне підприємство «Науково-експертний фармакопейний центр». 1-е вид. - Доп. 2. - Х.: Державне підприємство «Науково-експертний фармакопейний иентр», 2008. $620 \mathrm{c}$

6. Лукина Ю.И., Мариевич С.Ю. // Рациональная фармакотерапия в кардиол. - 2010. - №6. - С. 103-107.

7. Deshmukh N.D., Thenge R.R., Mahajan N.M. //Intern. J. of Pharmac. Res. and Bio-Sci. - 2012. - Vol. 1, №5. P. 364-378.

8. Public Assessment Report Decentralised Procedure Bisoprolol Fumarate $1.25 \mathrm{mg}, 2.5 \mathrm{mg}, 3.75 \mathrm{mg}, 5 \mathrm{mg}$, $7.5 \mathrm{mg}$ and $10 \mathrm{mg}$ Film-Coated Tablets UK/H/1683/001-6/DC UK licence no: PL 32256/0083-88 Applicant: Aurobindo Pharma (Malta) Limited. 
9. The Japanese Pharmacopoeia. $-16^{\text {th }}$ ed. $-2011 .-$ P. 463-464.

10. The United States Pharmacopeia. - 30 th ed. (NF 25). - Rockville: United States Pharmacopeial Convention Inc., 2007. $-1070 \mathrm{p}$.

\section{РОЗРОБКА ТЕСТУ «РОЗЧИНЕННЯ» ТАБЛЕТОК БІСОПРОЛОЛУ \\ О.О.Віслоус, Н.Ю.Бевз, В.А.Георгіяни, Н.В.Живора}

Ключові слова: бісопролол; таблетки; тест «розчинення»; спектрофоотометрія; валідація Бісопролол - ліпофрільний кардіоселективний $\beta$-адреноблокатор, який характеризується швидким і майже повним (до 90\%) всмоктуванням із шлунково-кишкового тракту та високою біодоступністю. Для визначення біодоступності твердих лікарських фрорм для внутрішнього застосування в умовах фрармацевтичних підприємств і лабораторій виконується тест «розчинення», результати якого дозволяють судити про дотримання технології виготовлення препарату та критеріїв його біологічної доступності. Випробування на розчинення твердих дозованих лікарських форм є невід'ємною частиною заходів, спрямованих на забезпечення якості лікарських засобів. Метою дослідження є розробка тесту «Розчинення» таблеток бісопрололу методом абсорбиійної спектрофотометрії в ультрафріолетовій та видимій областях спектра. В результаті дослідження обірунтовані умови для проведення тесту «Розчинення» бісопрололу фумарату в таблетках: використовували прилад з лопаттю; об'єм середовища - 500 мл; температура середовища розчинника $-37^{\circ} \mathrm{C}$; розчинник - 0,1 М розчин хлористоводневої кислоти; швидкість обертання - 75 об/хв, час розчинення - 20 хв. Розроблено спектрофоотометричну методику визначення бісопрололу фумарату в 0,1 М розчині кислоти хлористоводневої за довжини хвилі 272 нм. Встановлено, що допоміжні речовини таблеток не заважають спектрофотометричному визначенню. Одержані результати показали, що за 20 хв розчинення перейшло у розчин понад 90\% діючої речовини від їі номінального вмісту. Визначені валідаційні характеристики не перевищують критерії прийнятності: робасність (аналітичний розчин стабільний протягом години), лінійність (a=0,97\% $\leq$ max a, 1,92\%; $b=0,9931)$, коефріцієнт кореляції становить 0,9999, правильність $(0,52 \% \leq \max \delta, 0,96 \%)$ та збіжність (2,24\% $\leq \max \Delta a s, 3,0 \%)$, прецизійність (1,42\% $\leq \max \Delta a s$ 3,0\%), що дозволяє рекомендувати методику для використання у фармацевтичному аналізі.

\section{РАЗРАБОТКА ТЕСТА «РАСТВОРЕНИЕ» ТАБЛЕТОК БИСОПРОЛОЛА}

О.А.ВислоУс, Н.Ю.Бевз, В.А.ГеоргиянИ, Н.В.Живора

Ключевые слова: бисопролол; таблетки; тест «растворение»; спектрофотометрия; валидация

Бисопролол - липофильный кардиоселективный $\beta$-адреноблокатор, который характеризуется быстрым и почти полным (до 90\%) всасыванием из желудочно-кишечного тракта и высокой биодоступностью. Для определения биодоступности твердых лекарственных форм для внутреннего применения в условиях фрармацевтических предприятий и лабораторий выполняется тест «растворение», результаты которого позволяют судить о соблюдении технологии изготовления препарата и его биологической доступности. Испытания на растворение твердых дозированных лекарственных форм являются неотъемлемой частью мероприятий, направленных на обеспечение качества лекарственных средств. Целью исследования была разработка теста «Растворение» таблеток бисопролола методом абсорбционной спектрофотометрии в ультрафиолетовой и видимой областях спектра. В результате исследования обоснованы условия для проведения теста «Растворение» бисопролола фумарата в таблетках: использовали прибор с лопастью, объем среды - 500 мл, температура среды растворителя $-37^{\circ} \mathrm{C}$, растворитель - 0,1 M раствор хлористоводородной кислоты, скорость вращения - 75 об/мин, время растворения - 20 мин. Разработана спектрофотометрическая методика определения бисопролола фумарата в 0,1 M растворе кислоты хлористоводородной при длине волны 272 нм. Установлено, что вспомогательные вещества таблеток не мешают спектрофотометрическому определению. Полученные результаты показали, что за 20 мин растворения перешло в раствор более $90 \%$ действующего вещества от ее номинального содержания. Определенные валидационные характеристики не превышают критерии приемлемости: робастность (аналитический раствор стабилен в течение часа), линейность ( $a=0,97 \% \leq$ max $a, 1,92 \% ; b=0,9931)$, коэфрфициент корреляции составляет 0,9999, правильность $(0,52 \% \leq \max \delta, 0,96 \%)$ и сходимость $(2,24 \% \leq$ max $\Delta$ as, $3,0 \%)$, прецизионность (1,42\% $\leq$ max $\Delta$ as 3,0\%), что позволяет рекомендовать методику для использования в фрармацевтическом анализе. 